\title{
EFFECT OF STORAGE TIME AND TEMPERATURE ON SERA OF VENOUS BLOOD AND AL-HIJAMA BLOOD SAMPLES
}

\section{Adel A. M. Saeed ${ }^{1 *} \quad$ Galal AK. A. Sheikh ${ }^{2}$}

${ }^{1}$ Department of Chemistry, Faculty of Science, University of Aden, Aden-Yemen

${ }^{2}$ Department of Chemistry, Dr. Amin Nesher Higher Institute for Health Sciences, Aden-Yemen

*adel_saeed73@yahoo.com ; ORCID iD: 0000-0002-1154-2994

HNSJ, 2021, 2(12); https://doi.org/10.53796/hnsj2121

\section{Published at 01/12/2021}

\section{Accepted at 05/10/2021}

\begin{abstract}
Background: Blood serum and/or plasma is one of important biomarkers in laboratories to estimate the vital components of blood and is used to determine the healthy status of human and also to diagnose and treat diseases through laboratory results obtained through analysis of serum samples. Wet cupping therapy (WCT), also known as (Al-Hijamah) is one of the therapeutic techniques that were practiced in many countries of the world in ancient times and it is still used in many Islamic countries as considered as one of the beneficial treatment methods for many diseases.

Objective: The goal of this study is to identify the effect of storage time and temperature on some biochemical parameters of venous blood serum and compare these results with samples taken from the blood serum of wet cupping therapy, which was treated with the same conditions.

Method: Eighteen male participants were selected randomly between ages 25-61 years. About $5 \mathrm{ml}$ of blood samples were collected from the vein and cupping site for each participant and eight biochemical parameters that are glucose, urea, uric acid, creatinine, total cholesterol, triglycerides (TG), high density lipids (HDL), and low density lipids (LDL) were analyzed.

Results: All the parameters that were studied gave different results when they were studied at different storage periods i.e. zero time, $24 \mathrm{~h}, 48 \mathrm{~h}$, and $72 \mathrm{~h}$ and at different temperatures (room temperature $\left(26 \pm 1{ }^{\circ} \mathrm{C}\right.$ ) and $\left.2 \pm 1{ }^{\circ} \mathrm{C}\right)$. Glucose and high density lipids showed a decrease in concentration with the increase in storage time, while total cholesterol, triglycerides, low density lipids. and uric acid increased their concentration with storage time. Urea and creatinine did not change during the storage period.

Conclusion: We recommend avoiding storing the serum for a long period and analyzing it at tested temperatures as soon as possible.
\end{abstract}

Keywords: Temperature, Storage time, Venus serum, Cupping therapy serum, Biological parameters 


\section{تأثير زهن التخزين والحرارة على أهصال عينات دم الوريد والهجاهة}

\section{عادل أحمد محمد سعيد1،*، جلال الخضر عبدالله شيخ²}

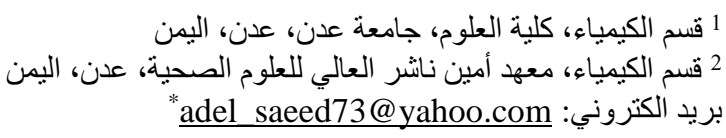

المعرف العلمي: 0000-0002-1154-2994

HNSJ, 2021, 2(12); https://doi.org/10.53796/hnsj2121

$$
\text { تاريخ القبول: 2021/10/05م }
$$

تاريخ النشر: 2021/12/01م

\section{المستخلص}

الخلفية: يعد مصل أو/و بلازما الدم احد المعلمات الحيوية المهمة في المختبرات لتقييم المكونات الهامة في الدم ويستخدم لتقدير

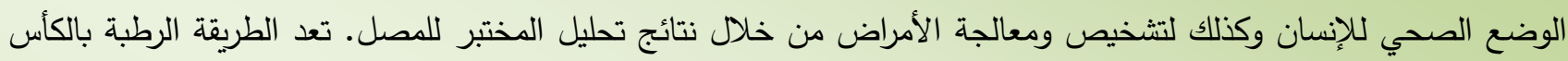
(وتعرف أيضا بالحجامة) واحدة من تقنيات العلاج المستخدمة عمليا في عدد من بلدان العالم في الحقب الماضية ولاتزال تستخدم

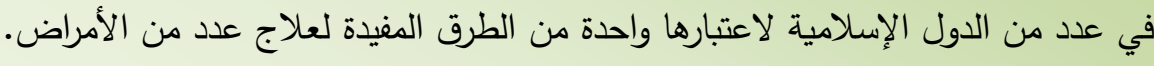
الهاف: تهدف الدراسة لتحديد مدى تاثير زمن الخزن والحرارة على بعض المعلمات الدات الحيوكيميائية في مصل دم الوريد ومقارنة هذه

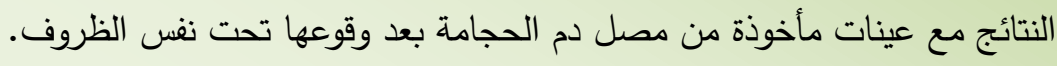

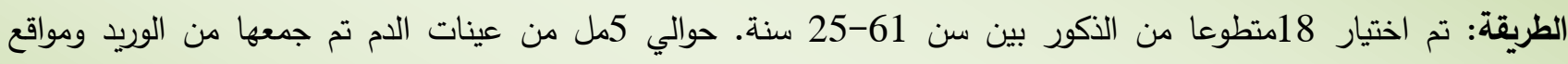
الحجامة لكل متطوع وتم تحليل 8معلمات حيوكيميائية: دم الجلوكوز، اليوريا، حض الئلين اليوريك، الكيراتينين، الكوليسترول الكلي، الجليسريدات الثلاثية، الليبيدات عالية الكثافة، والليبيدات منخفظة الكثافة.

النتائج: أعطت جميع المعلمات المدروسة نتائج مختلفة عند دراستها تحت فترات تخزين مختلفة (زمن الصفر، 24 ساعة، 48ساعة،72 ساعة) عند درجات حرارة الغرفة

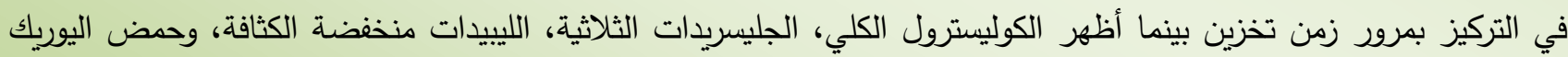
ارتفاعا في التركيز بمرور الزمن. لم يظهر كلا من اليوريا والكيراتينين لم يظهرا تغيرا ملحوظا عند نفس الفترات الزمنية المدروسة.

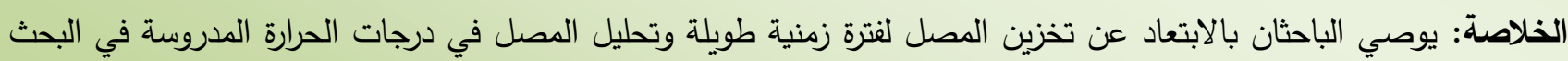
الحالي بأسرع وقت ممكن. الكلمات المفتاحية: درجة الحرارة، زمن التخزين، مصل الوريد، مصل الحجامة، المعلمات الحيوكيميائية 


\section{INTRODUCTION}

Serum and/or plasma analysis is an important and reliable clinical method for estimating an individual's health status. The goal of blood tests for patients and healthy people is to assess the health of the body and its organs by estimating the level of biochemical, immunological, and metabolic components, and accurate measurements of clinical biochemical variables are necessary to correct abnormal conditions [1]. The general problem that leads clinical laboratories to make errors in the results issued by these laboratories is the prolonged contact of the serum with blood cells, and this is one of the main reasons for the error results [2, 3]. Also, these results are usually used by doctors to diagnose various diseases, so any error in these results leads in turn to an error in the diagnosis and also an error in the medications given to this patient. In clinical pathology, analysis of plasma or serum samples is an essential tool to ascertain the toxic effect of a test chemical. However, the integrity of the results depends not only on the analytical tools and equipment used but also on several factors that influence, primarily pre-analytical, analytical, or normal biological differences, the accuracy of test results. Pre-analytical relies on factors such as collecting samples and storing serum and other blood fluids in appropriate conditions to preserve samples used for research or collection for routine work, diet, exercise, and medications. Another important that must be taken into account to obtain reliable results, is the need to adjust the period between blood collection and separation [4]. In general, serum samples for a clinical/chemical analysis are refrigerated (from $2 \pm 1$ to $8 \pm 1{ }^{\circ} \mathrm{C}$ ) or frozen (from $-10 \pm 1$ to $-20 \pm 1{ }^{\circ} \mathrm{C}$ ) for short periods and stored at $-70 \pm 1{ }^{\circ} \mathrm{C}$ for extended periods. Information regarding the stability of commonly used clinical biochemical analyses in human serum is available including the effect of storage temperatures around $-20 \pm 1^{\circ} \mathrm{C}$ on separated serum. Therefore, the study examined the stability of some biochemical variables in serum samples in serum separated from cells immediately after storage at a specified temperature for different periods [5]. Various studies have examined how storage conditions affected the stability of different blood components. However, there is less information about the stability of commonly used chemical analyses in human sera [6-8].

Alternative medicine and traditional treatments have become today one of the methods that are relied upon to treat many diseases, and research is beginning to go towards researching this type of treatment method, and one of such is cupping therapy. Cupping therapy is one of the ancient healing methods that were used in many ancient countries in the East and West, and the strongest evidence for this treatment appears to be the Ebers Papyrus, a medium textbook dating back to $1550 \mathrm{BC}$ that was found in the tomb of King Tut. Also, this therapeutic method was adopted by the Greeks and Romans, and this was evident in the methods adopted by Hippocrates and Galen [9].

There are two main methods of cupping therapy, dry cupping, and wet cupping. Dry cupping treatment depends on generating negative pressure on the area suffering from the disease, which in turn leads to the movement of subcutaneous fluids. As for the treatment of wet cupping, it is done by making incisions in the skin of the affected area and then applying negative pressure to this area, which leads to the expulsion of blood along with what contains harmful substances in the body. While dry cupping therapy is one of the most popular methods in traditional Chinese medicine, wet cupping therapy is the method known as Al-Hijamah, which is more popular among Muslim 
communities because it is one of the honorable prophetic medicines, which was urged as stated in many prophetic hadiths [10].

Avicenna (called Ibn Sina) spoke in detail about the mechanisms of wet cupping therapy. He stated that the confusion in the disturbed parts of the body explains the cause of the pain and inflammation, which must be absorbed to the surface and evacuated from that point in au der to relieve the discomfort. Among the scholars of his time who considered wet cupping therapy as a way to cleanse the body of dangerous substances [11].

Loukas et al. mentioned that medical knowledge gained from the Qur'an (God's words) and hadiths (the words of the Prophet Muhammad, may God bless him and grant him peace) can be an important source for human medicine in light of their astonishing agreement with modern medical knowledge [12].

In continuous with our other study [13], the goal of this study is to identify the effect of storage time and temperature on some biochemical tests of venous blood serum and compare these results with samples taken from the blood serum of cupping therapy at the same conditions.

\section{MATERIALS AND METHODS}

The devices and materials used in this study include COBAS INTEGRA 400 plus from Roche (Germany), 800 Centrifuge $4000 \mathrm{rpm}$ (Germany). Deionized water made in Yemen by UMCO pharm, polyethylene plastic bottles, a tube contains Gel and Clot Activator (Italy), refrigerated (Germany).

Clinical trials have been carried out in two specialized centers for cupping therapy located in the city of Aden, Yemen, as well as in National Center of Public Health Laboratories, Khormaksar-Aden, and the Laboratories of Al-Gamhuria Modern General Hospital, Khormaksar-Aden, Yemen from December 2019 to January 2021 was a single-arm, pre-and post-test interventional study. We went to the specialized center for wet cupping therapy (WCT) to make advertisements to receive the volunteers for this study and check their eligibility for this study through the physical examination and the relevant questionnaires. The first center specialized in wet cupping therapy (WCT) is located in the middle of the city of Al-Haswa. Many people come to this center looking for cupping therapy and other types of folk medicine. The second site is the Physiotherapy and Alternative Medicine Clinic, which is located next to Al-Naqib Hospital, in the city of Al-Mansoura where people come for physiotherapy sessions as well as for WCT. During the arrival at the specialized center for wet cupping therapy, 15 people were received in the first center while 13 people in the second center, they were selected for these clinical trials, with the exclusion of people who have diseases that prevent cupping therapy to apply on, as well as those who take daily medications. Among the 28 people, 7 people were excluded. Before starting wet cupping therapy, 3 people withdrew, and 18 people completed the study (Figures 1). Samples $(n=18)$ were collected from the volunteers whose ages ranged between $25-61$ years, on average $(38.8 \pm 11.4)$. 


\section{Ethical Considerations}

This study was done as in partial fulfillment of the requirements for a master's degree in Chemistry by the Faculty of Education, University of Aden, Yemen, with the approval of the University's Graduate Studies Council. The practical protocol was consistent with the Declaration of Helsinki and permitted by the local ethics committee.

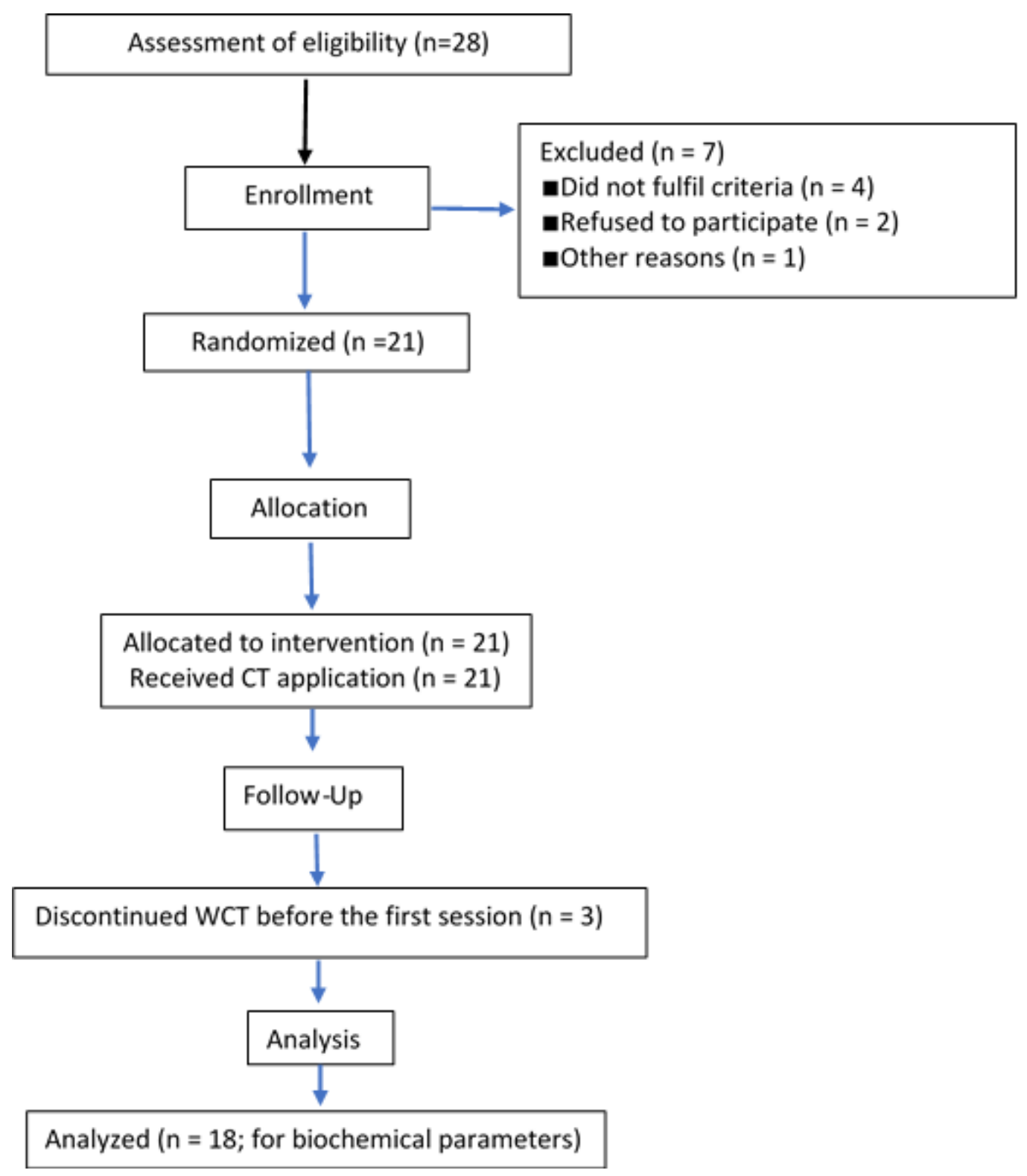

Figure 1: Associate flowchart of the study

\section{Cupping Therapy (Al-Hijamah) Application}

Al-Hijamah technique was applied on the three days of the lunar months in the morning. Volunteers were overnight fasting then the participants were seated on the chair so the vacuum glass cup is fitted to the surface of the back. The skin was cleaned with the sterilized solution prior procedure. The cupping puts tightly on the cleaning area. The suction connected to the cup quickly. It was maintained until the skin pulled up within the cup. Applied pressure monitored with the height of skin dome elevation one centimeter into the cup on the time of sucking for less than two minutes. Subsequently, the suction stopped and the cup was slowly removed. The cleaned skin 
was cut in some parallel longitude lines with the sterilized blade along the vertebral column, 5-7 mm. Once again, cupping was applied. The blood oozed due to suction pressure with a duration of fewer than $3 \mathrm{~min}$. In the end, blood samples were collected for laboratory investigation.

\section{Biochemical Analysis}

Total blood samples were placed in test tubes and left to coagulate at room temperature for $20 \mathrm{~min}$ and then separated by centrifuge at a speed of $3500 \mathrm{rpm}$ for $5 \mathrm{~min}$. Then, directly fasting sugar (glucose), urea, uric acid, creatinine, total cholesterol, triglycerides (TG), high density lipids (HDL), and low density lipids (LDL) were studied in 18 serum samples at zero time. Then serum samples of each subject were pooled into a plain tube and then liquated into $1.5 \mathrm{~mL}$ Eppendorf tubes; two aliquots per subject were kept. The first part was analyzed at room temperature $\left(26 \pm 1^{\circ} \mathrm{C}\right)$, the second part was kept in the refrigerator $\left(2 \pm 1^{\circ} \mathrm{C}\right)$, then the effect of different temperatures was studied over time, as samples were analyzed at zero time, $24 \mathrm{~h}, 48 \mathrm{~h}$, and $72 \mathrm{~h}$ (see Table (1)).

\section{Statistical analysis}

Statistical analysis of the results was performed using Microsoft Excel 2019 and SPSS version 25. ANOVA test was applied to compare among the different time points of the P-value $<0.05$ was considered significant.

Table 1: Shows the division of samples to analyze the effect of temperature

\begin{tabular}{|c|c|c|c|c|c|}
\hline $\begin{array}{c}\text { Sample } \\
\text { No. }\end{array}$ & $\begin{array}{c}\text { Sample } \\
\text { label }\end{array}$ & Sample type & $\begin{array}{c}\text { Sample } \\
\text { volume }\end{array}$ & Temperature & Time of analysis \\
\hline $\mathbf{1}$ & $1 / \mathrm{c}$ & $\begin{array}{c}\text { Venous blood } \\
\text { serum }\end{array}$ & $1.5 \mathrm{ml}$ & $26 \pm 1^{\circ} \mathrm{C}$ & $\begin{array}{r}\text { Zero time, } 24 \mathrm{~h}, \\
48 \mathrm{~h}, \& 72 \mathrm{~h} .\end{array}$ \\
\hline $\mathbf{2}$ & $1 / \mathrm{d}$ & $\begin{array}{r}\text { Venous blood } \\
\text { serum }\end{array}$ & $1.5 \mathrm{ml}$ & $2 \pm 1^{\circ} \mathrm{C}$ & $\begin{array}{r}\text { Zero time, } 24 \mathrm{~h}, \\
48 \mathrm{~h}, \& 72 \mathrm{~h} .\end{array}$ \\
\hline $\mathbf{3}$ & $2 / \mathrm{c}$ & $\begin{array}{c}\text { Cupping } \\
\text { therapy blood } \\
\text { serum }\end{array}$ & $1.5 \mathrm{ml}$ & $26 \pm 1^{\circ} \mathrm{C}$ & $\begin{array}{r}\text { Zero time, } 24 \mathrm{~h}, \\
48 \mathrm{~h}, \& 72 \mathrm{~h} .\end{array}$ \\
\hline $\mathbf{4}$ & $2 / \mathrm{d}$ & $\begin{array}{c}\text { Cupping } \\
\text { therapy blood } \\
\text { serum }\end{array}$ & $1.5 \mathrm{ml}$ & $2 \pm 1^{\circ} \mathrm{C}$ & $\begin{array}{r}\text { Zero time, } 24 \mathrm{~h}, \\
48 \mathrm{~h}, \& 72 \mathrm{~h} .\end{array}$ \\
\hline
\end{tabular}




\section{RESULTS AND DISCUSSION}

All participants in the recent work were males. The collected information (Table 2) from the questionnaire showed that the age of the participants was between $(25-61)$ years with a median age of $39.7 \pm 11.7$.

Table 2: Characteristics of the participants

\begin{tabular}{|l|l|}
\hline Variable & Participant $(\mathbf{N}=18)$ \\
\hline Age $($ Median \pm SD) & $*$ \\
\hline Gender & $39.7 \pm 11.7$ \\
\hline Male & $100 \%$ \\
\hline Smoking & \\
\hline Smoker & $46 \%$ \\
\hline Previous CT & $53 \%$ \\
\hline Yes & \\
\hline No & $53.3 \%$ \\
\hline
\end{tabular}

* SD: Standard division.

This study was conducted to know the effect of storage and temperature on eight routinely measurements of biochemical parameters in venous serum samples stored at $\left(2 \pm 1^{\circ} \mathrm{C}\right)$ and at room temperature $\left(26 \pm 1^{\circ} \mathrm{C}\right)$ and comparing these results with that of wet cupping therapy serum samples under the same conditions.

It should be noted from Tables ( 3 and 4 ) that when using the ANOVA test at the $\mathrm{p}<0.05$ level, some parameters in the results of serum analysis were affected by the storage period at room temperature of $26 \pm 1^{\circ} \mathrm{C}$ and also in the refrigerator at $2 \pm 1^{\circ} \mathrm{C}$, and this effect differed from one substance to another.

Glucose in venous serum showed stability in concentration in the storage time (zero time-72h) and at both investigation temperatures while in WCT serum it decreased with time at $2 \pm 1^{\circ} \mathrm{C}$ and $26 \pm 1^{\circ} \mathrm{C}$ (Tables 3,4 and Fig.2).

Boyanton and Blick finalized in their study that storage at $25^{\circ} \mathrm{C}$ and after $24 \mathrm{~h}$ led to a decrease in concentration [2].

Saeed et al. found that at $4-5{ }^{\circ} \mathrm{C}$ and within 6days, glucose stayed unchanged in its concentration but at room temperature, it showed decreasing in its concentration after 3day storage time [14].

Cuhadar et al. demonstrated that either at $4^{\circ} \mathrm{C}$ or room temperature there was decreasing in concentration started in the first $h$ of storage [15].

Dirar et al. in their work appeared that there is a reciprocal relationship between storage time and temperature decreasing concentration where $24 \mathrm{~h}$ and at $23^{\circ} \mathrm{C}$ and 48 $\mathrm{h}$ at $4^{\circ} \mathrm{C}$ affected glucose concentration [16].

Urea substance in our study was mostly stable in investigation experiment conditions for both serum samples (i.e. V and WCT).

In comparison with other studies, it found no effect on the concentration of urea at $4{ }^{\circ} \mathrm{C}$ and $23^{\circ} \mathrm{C}$ up to $72 \mathrm{~h}$ and can continue stable up to 10 days at $-20^{\circ} \mathrm{C}[16,17]$.

For uric acid concentration parameter (Tables 3,4 and Fig.3), we concluded that it was mostly stable in our experimental conditions (i.e. zero time-72h and at $2 \pm 1^{\circ} \mathrm{C}$ and $26 \pm 1^{\circ} \mathrm{C}$ ) except in WCT serum were decreased at $26 \pm 1 \mathrm{C}$ at $72 \mathrm{~h}$ storage time.

One study [18] showed that uric acid can be stable for 4 days at $9^{\circ} \mathrm{C}$ but its 
concentration increase at room temperature. Another research did not find any effect on uric acid concentration in serum samples up to $72 \mathrm{~h}$ at two degrees of temperature (i.e. $4 \pm 1^{\circ} \mathrm{C}$ and $23 \pm 1^{\circ} \mathrm{C}$ ) [16].

Creatinine substance was fixed in concentration in $0-72 \mathrm{~h}$ and at $2 \pm 1^{\circ} \mathrm{C}-26 \pm 1^{\circ} \mathrm{C}$ except for creatinine in WTC serum at $26 \pm 1^{\circ} \mathrm{C}$ that showed concentration increased.

In comparison with other works, creatinine increased in $24 \mathrm{~h}$ storage time at $25^{\circ} \mathrm{C}$ and become unstable when storage at $-20^{\circ} \mathrm{C}$ for up to 10 days $[2,17]$.

For total cholesterol concentration in our samples (Fig.4), it showed a small increase in $\mathrm{V}$ serum at $2 \pm 1^{\circ} \mathrm{C}$ and $26 \pm 1^{\circ} \mathrm{C}$ and after $24 \mathrm{~h}$ on one side. For WCT serum, on the other side, total cholesterol increase in its concentration at $26 \pm 1^{\circ} \mathrm{C}$ after $24 \mathrm{~h}$ and statistically increase at $2 \pm 1^{\circ} \mathrm{C}$ when reaches $72 \mathrm{~h}$. In contrast, several studies showed no change in the concentration started from $72 \mathrm{~h}$ up to 9 days at $4^{\circ} \mathrm{C}$-room temperature [14-16].

TG in all our investigated samples as shown in Fig. 5 had a statistical increase in concentration after $24 \mathrm{~h}$. While TG showed stability from $72 \mathrm{~h}-4$ days at temperature ranged $4^{\circ} \mathrm{C}-\mathrm{RT}[15,16]$ except in [18] study that found an increase in concentration in 4 days at RT.

For HDL investigation, we found no change effect on the concentration in two types of serum samples at $2 \pm 1^{\circ} \mathrm{C}$ and $26 \pm 1^{\circ} \mathrm{C}$ as long as $48 \mathrm{~h}$. But concentration decreased statistically when reached $72 \mathrm{~h}$.

Heins et al. in their research showed no effect at $9^{\circ} \mathrm{C}$ for 4 days storage but the concentration increase when applying the RT condition [18].

Cuhadar et al. however, concluded that keeping serum sample 3days at room temperature make HDL concentration unstable [15].

LDL (Fig. 6) at $2 \pm 1^{\circ} \mathrm{C} \mathrm{V}$ serum samples were stable as long as $72 \mathrm{~h}$ while WCT serum samples appeared significant differences at $\mathrm{p}<0.05$ started between zero time and after $24 \mathrm{~h}$ when applying $2 \pm 1^{\circ} \mathrm{C}$ and $26 \pm 1^{\circ} \mathrm{C}$. V serum shows the same result but at $26 \pm 1^{\circ} \mathrm{C}$ only.

Saeed et al. [14] found that at room temperature LDL decreased in one day and can be stable until 6 days at $4-5^{\circ} \mathrm{C}$.

Bilal with his team noted that there are unknown substances that may be in the treatment of cupping, and these substances when they leave the body, the body returns to the equilibrium mechanism of the vital substances, and these substances may have an effect on the decomposition of some substances with a greater percentage than the blood of the vein [19].

Gok et al. believed that cupping therapy has an effect in removing toxic substances from the body with the blood that is expelled during the process of cupping therapy, and therefore these substances may affect the vital parameters that have been studied in the serum of cupping therapy [20]. 
Table 3: Shows the effect of storage period and temperature on the biological parameters of venous blood serum

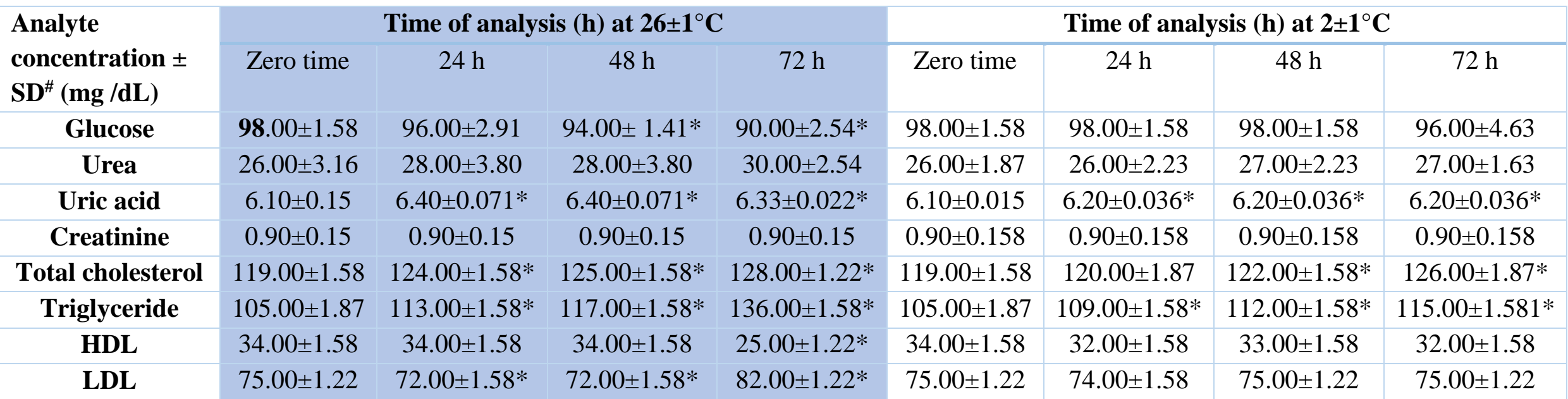

Table 4: Represents the effect of storage period and temperature on the bioanalysis parameters of WCT blood serum

\begin{tabular}{|c|c|c|c|c|c|c|c|c|}
\hline \multirow{2}{*}{$\begin{array}{l}\text { Analyte } \\
\text { concentration } \pm \\
\text { SD\# }(\mathbf{m g} / \mathbf{d L})\end{array}$} & \multicolumn{4}{|c|}{ Time of analysis (h) at $26 \pm 1^{\circ} \mathrm{C}$ of WCT } & \multicolumn{4}{|c|}{ Time of analysis (h) at $2 \pm 1^{\circ} \mathrm{C}$ of WCT } \\
\hline & Zero time & $24 \mathrm{~h}$ & $48 \mathrm{~h}$ & $72 \mathrm{~h}$ & Zero time & $24 \mathrm{~h}$ & $48 \mathrm{~h}$ & $72 \mathrm{~h}$ \\
\hline Glucose & $94.00 \pm 2.91$ & $93.00 \pm 4.74 *$ & $46.00 \pm 2.70^{*}$ & $20.00 \pm 0.06^{*}$ & $94.00 \pm 1.58$ & $94.00 \pm$ & $93.00 \pm 1.64$ & $92.00 \pm 1.41$ \\
\hline Uric acid & $6.20 \pm 0.036$ & $6.40 \pm 0.071^{*}$ & $6.40 \pm 0.071^{*}$ & $4.02 \pm 0.015^{*}$ & $6.20 \pm 0.036$ & $6.40 \pm 0.071^{*}$ & $6.40 \pm 0.071^{*}$ & $6.40 \pm 0.071^{*}$ \\
\hline Creatinine & $0.80 \pm 0.158$ & $0.80 \pm 0.158$ & $0.90 \pm 0.158$ & $1.30 \pm 0.158^{*}$ & $0.80 \pm 0.158$ & $0.80 \pm 0.158$ & $0.90 \pm 0.158$ & $0.80 \pm 0.158$ \\
\hline HDL & $41.00 \pm 1.58$ & $41.00 \pm 1.58$ & $41.00 \pm 1.58$ & $32.00 \pm 1.58 *$ & $41.00 \pm 1.58$ & $40.00 \pm 1.58$ & $40.00 \pm 1.58$ & $40.00 \pm 1.58$ \\
\hline LDL & $93.00 \pm 1.58$ & $87.00 \pm 1.22 *$ & $92.00 \pm 1.22$ & $99.00 \pm 1.22 *$ & $93.00 \pm 1.58$ & $91.00 \pm 1.22 *$ & $91.00 \pm 1.22 *$ & $91.00 \pm 1.22 *$ \\
\hline
\end{tabular}

${ }^{\#}$ Mean \pm SD, * Statistically significant difference $(\mathrm{p}<0.05)$. 


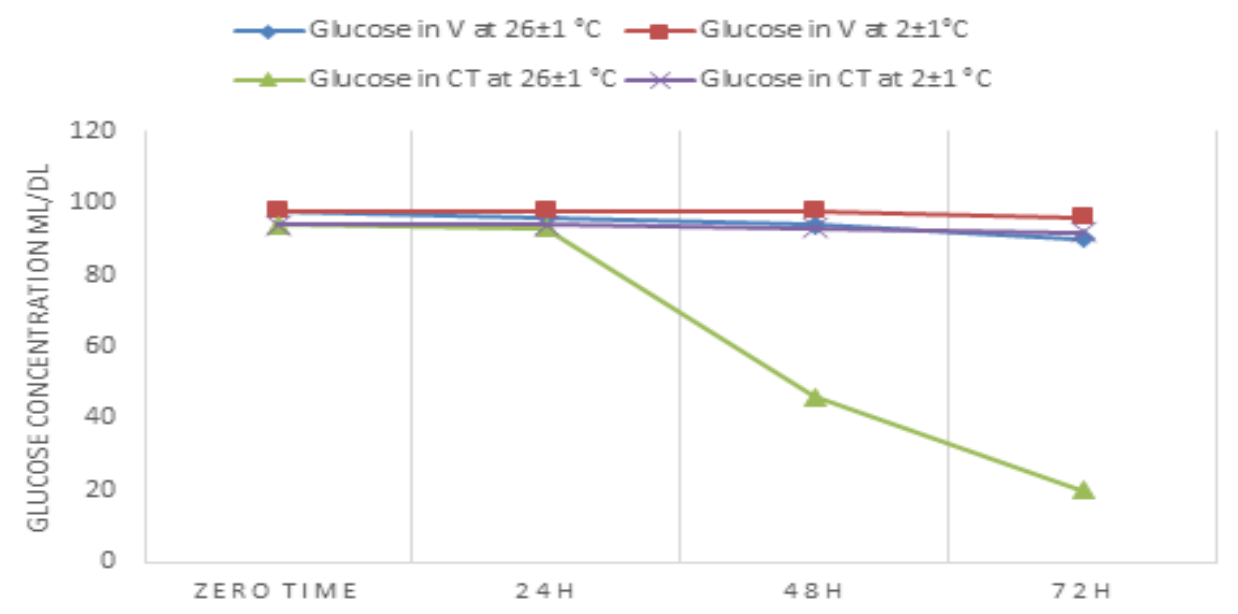

Figure 2: Shows the change in the concentration of glucose in the V blood serum and the blood serum of WCT over time
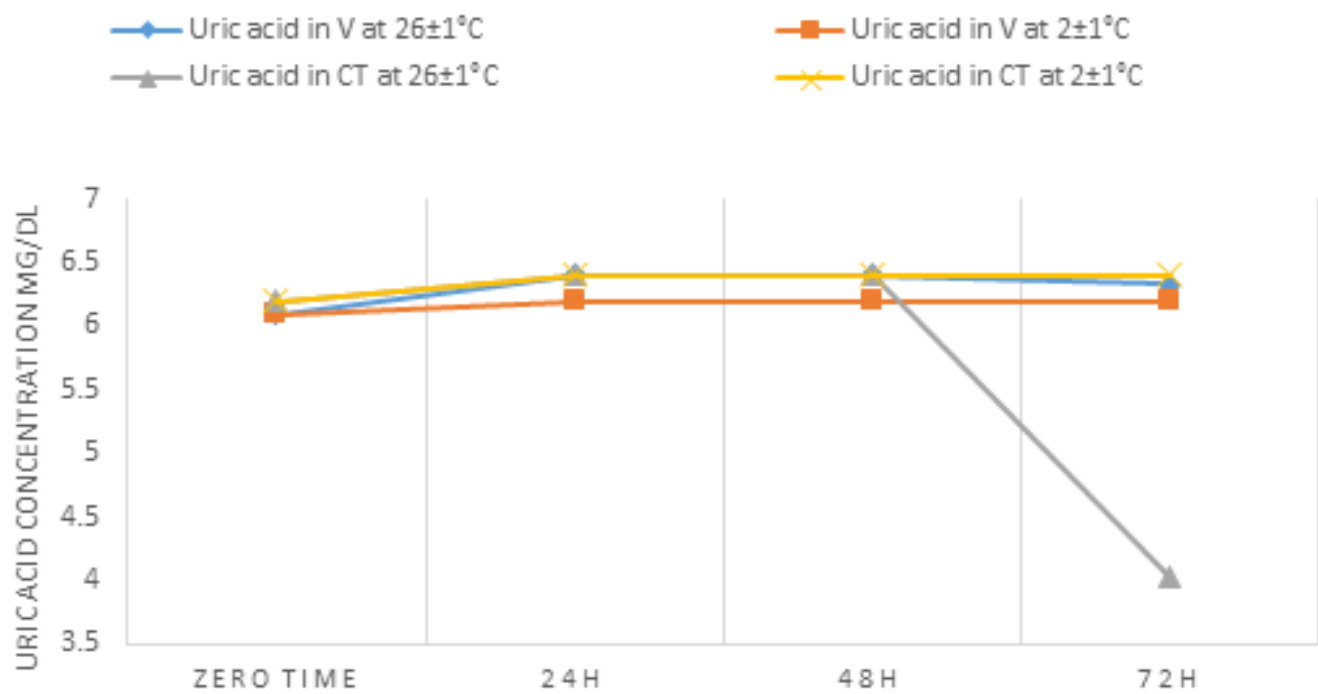

Figure 3: The change in the concentration of uric acid in the V blood and the blood of WCT over time
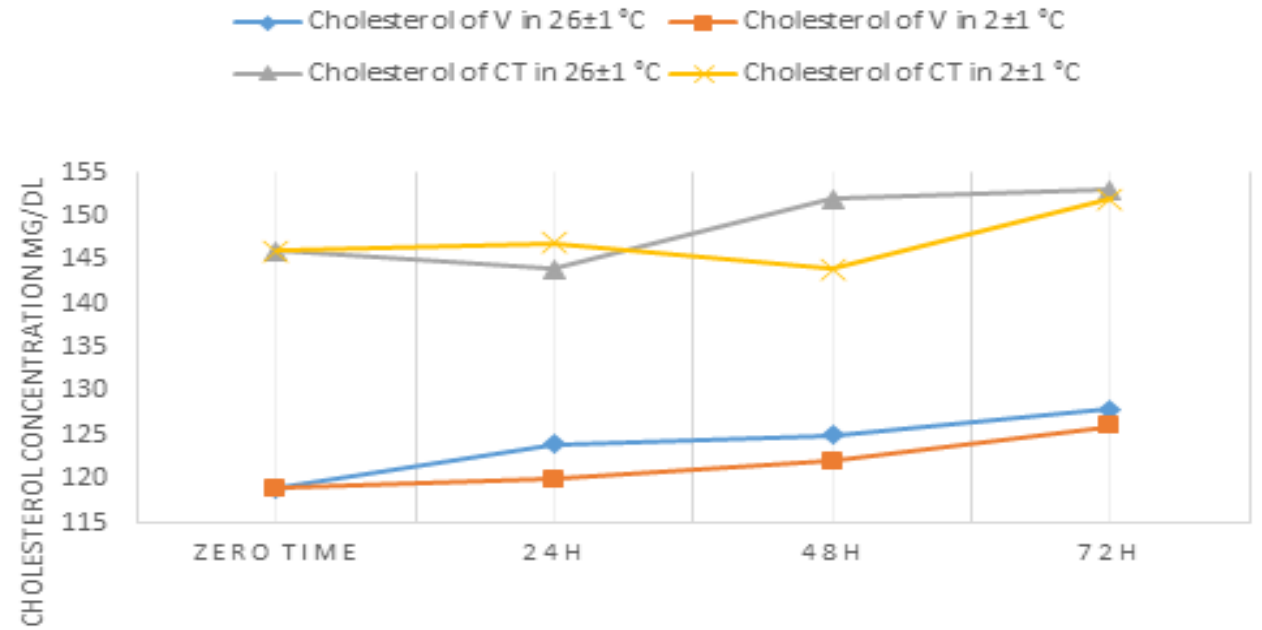

Figure 4: Represents the change in the concentration of cholesterol in the V blood and the blood of WCT over time 


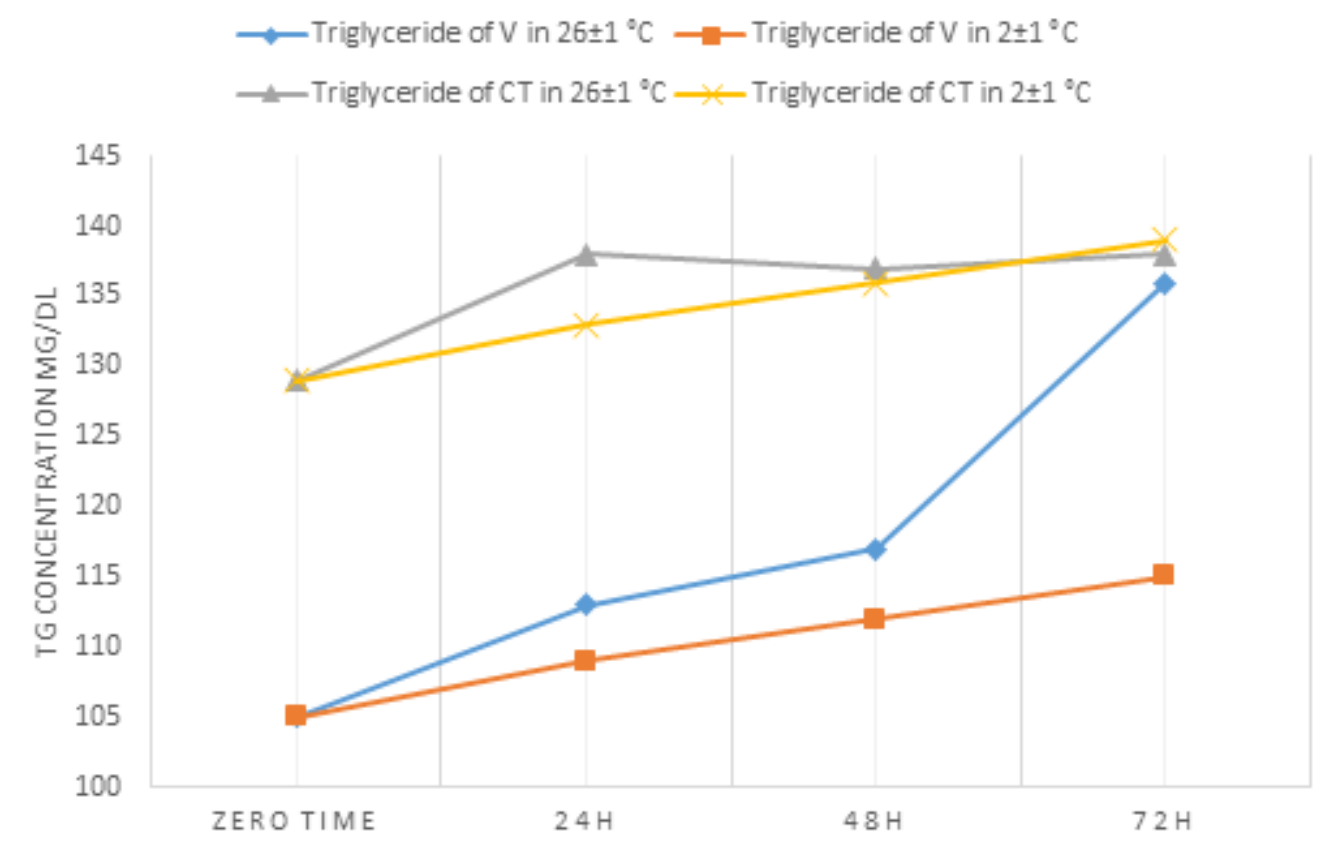

Figure 5: Profile of the change in the concentration of triglyceride (TG) in both studied serums over time

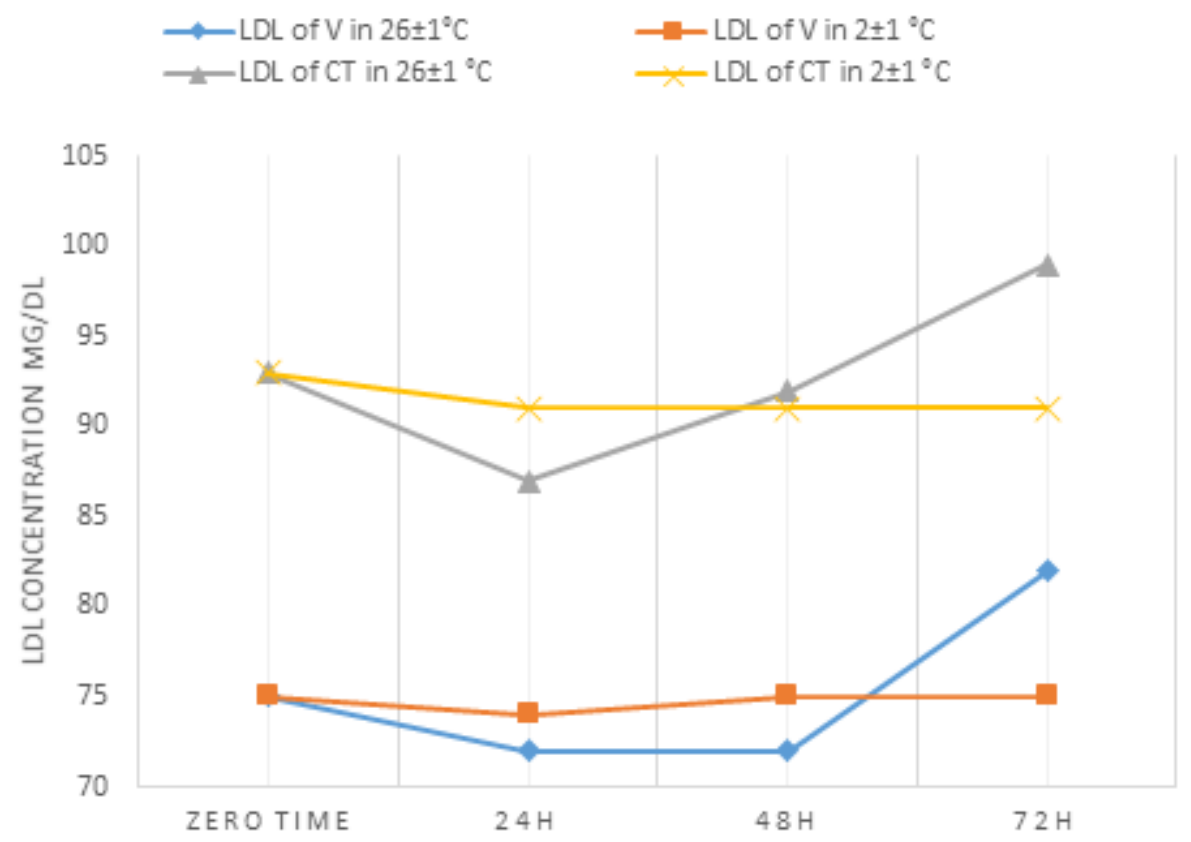

Figure 6: Indications the change in the concentration of LDL in the V and WCT blood serums over time 


\section{CONCLUSION}

In this study, we examined the effect of storage and temperature on eight biochemical analyzes in pooled serum samples stored at room temperature of $26 \pm 1{ }^{\circ} \mathrm{C}$ and in a refrigerator at $2 \pm 1{ }^{\circ} \mathrm{C}$. It was also compared with samples taken from the blood serum of wet cupping therapy, where it was found that some samples had an increase in the concentration within the time range, while others had a decrease in their concentration in comparison with the zero-time concentration.

After 48h, cholesterol showed statistically significant differences at $\mathrm{p}<0.05$ when compared with zero time. However, glucose, urea, creatinine, HDL, and LDL did not show any statistically significant differences at $\mathrm{p}<0.05$ in comparison with zero time.

Through this, we found that among the eight analytes of intravenous serum, only uric acid and triglycerides had the same effect when stored at $26 \pm 1^{\circ} \mathrm{C}$ and at $2 \pm 1{ }^{\circ} \mathrm{C}$, where they showed an increase in the concentration at both tested temperatures.

At $26 \pm 1^{\circ} \mathrm{C}$, uric acid, total cholesterol, $\mathrm{TG}$, and LDL had a greater effect, as there had significant differences $(\mathrm{p}<0.05)$ between zero time and after $24 \mathrm{~h}$.

We recommend that the blood serum be separated from the clots as soon as possible, and it is preferable to analyze them at room temperature or $2 \pm 1{ }^{\circ} \mathrm{C}$ before $24 \mathrm{~h}$ have passed since collecting the blood sample, to avoid obtaining incorrect results of biological parameters and to avoid storing blood samples for a long time.

\section{REFERENCES}

[1.] Merzah, K.S., \& Sabee, Q.S. (2021). The storage time and temperature effect on the stability of some biochemical variables in sera samples, Annals of Tropical Medicine \& Public Health, 24(S2): $\quad$ SP24228. http://doi.org/10.36295/ASRO.2021.24228

[2.] Boyanton Jr, B.L. and Blick, K.E. (2002). Stability studies of twenty-four analytes in human plasma and serum. Clinical Chemistry, 48(12), 2242-2247.

[3.] Plebani, M. (2006). Errors in clinical laboratories or errors in laboratory medicine?. Clinical Chemistry and Laboratory Medicine (CCLM), 44(6), 750759.

[4.] Marjani, A. (2008). Effect of storage time and temperature on serum analytes. American Journal of Applied Sciences, 5(8), 1047-1051.

[5.] Kale, V. P., Patel, S. G., Gunjal, P. S., Wakchaure, S. U., Sundar, R. S., Ranvir, R. K., \& Jain, M. R. (2012). Effect of repeated freezing and thawing on 18 clinical chemistry analytes in rat serum. Journal of the American Association for Laboratory Animal Science, 51(4), 475-478.

[6.] Männistö, T., Surcel, H.M., Bloigu, A., Ruokonen, A., Hartikainen, A. L., Järvelin, M.R., Pouta, A., Vääräsmäki, M., \& Suvanto-Luukkonen, E. (2007). The effect of freezing, thawing, and short- and long-term storage on serum thyrotropin, thyroid hormones, and thyroid autoantibodies: implications for analyzing samples stored in serum banks. Clinical Chemistry, 53(11), 19861987.

[7.] Gao, Y.C., Yuan, Z.B., Yang, Y.D., \& Lu, H.K. (2007). Effect of freeze-thaw cycles on serum measurements of AFP, CEA, CA125, and 
CA19-9. Scandinavian Journal of Clinical and Laboratory Investigation, 67(7), 741-747.

[8.] Zivkovic, A.M., Wiest, M.M., Nguyen, U.T. et al (2009). Effects of sample handling and storage on quantitative lipid analysis in human serum. Metabolomics 5, 507-516. DOI: http://doi.org/10.1007/s11306-009-0174-2

[9.] Ahmedi, M., \& Siddiqui, M. R. (2014). The value of wet cupping as a therapy in modern medicine-An Islamic Perspective. WebmedCentral Alternative Medicine, 5(12),WMC004785

[10.] Benli, A.R. \& Ersoy, S. (2020). The effect of wet cupping therapy on heavy metal levels: a single-arm clinical trial. Iranian Red Crescent Medical Journal, 22(4).(In Press):e96348. DOI: http://doi.org/10.5812/ircmj.96348

[11.] El Sayed, S.M., Al-quliti, A.S., Mahmoud, H.S., Baghdadi, H., Maria, R.A., Nabo, M.M.H., \& Hefny, A. (2014). Therapeutic benefits of Al-hijamah: in light of modern medicine and prophetic medicine. American Journal of Medical and Biological Research, 2(2), 46-71. DOI: http://doi.org/10.12691/ajmbr-2-2-3

[12.] Loukas, M., Saad, Y., Tubbs, R.S., \& Shoja, M.M. (2010). The heart and cardiovascular system in the Qur'an and Hadeeth. International Journal of Cardiology, 140(1), 19-23.

[13.] Adel A.M. Saeed, Wafa F.S. Badulla, Galal AK. A. Sheikh (2021). The effect of wet cupping therapy (al-hijamah) on some blood components: A comparative study. Electronic Journal of University of Aden for Basic and Applied Sciences, 2(3),124-130. https://doi.org/10.47372/ejua-ba.2021.3.106

[14.] Saeed, A., Afzal, M., \& Akhtar, S. (1995). Effect of storage on some constituents of camel serum. Australian Veterinary Journal, 72(6), 212-215.

[15.] Cuhadar, S., Atay, A., Koseoglu, M., Dirican, A.I., Hur, A. (2012). Stability studies of common biochemical analytes in serum separator tubes with or without gel barrier subjected to various storage conditions. Biochemia Medica, 22 (2), 202-214.

[16.] Dirar, A., Abdallah, D.A., \& Abdelsalam, K.E.A. (2010). Effect of storage time and temperature on some serum analytes. International Journal of Pathology, 8(2), 68-71.

[17.] Vernekar, N.V. \& Jabannavar, V.B. (2017). Effect of storage and temperature on two biochemical analytes (creatinine and urea) in pooled serum samples stored at- $20^{\circ}$ C. Indian Journal of Health Sciences and Biomedical Research (KLEU), 10(1), 63-67. DOI: http://doi.org/10.4103/2349-5006.198591

[18.] Heins, M., Heil, W., \& Withold, W. (1995). Storage of serum or whole blood samples? Effects of time and temperature on 22 serum analytes. Eur J Clin Chem Clin Biochem. 33 (4),231-238.

[19.] Bilal, M., Khan, R. A., \& Afroz, S. (2011). Partial evaluation of technique used in cupping therapy. Journal of Basic \& Applied Sciences, 7(1), 65-68.

[20.] Gok, S., Kazanci, F. H., Erdamar, H., Gokgoz, N., Hartiningsih, S., \& Dane, S. (2016). Is it possible to remove heavy metals from the body by wet cupping therapy (Al-hijamah)?. Indian Journal of Traditional Knowledge. 15(4),700704. 